\title{
Insulin Binding and Activation of Glycogen Synthase in Fibroblasts from Type 1 (Insulin-Dependent) Diabetic Patients
}

\author{
J.M.Podskalny and C. R. Kahn
}

Section on Cellular and Molecular Physiology, Diabetes Branch, National Institute of Arthritis, Diabetes, Digestive and Kidney Diseases, National Institutes of Health, Bethesda, Maryland USA

\begin{abstract}
Summary. ${ }^{125}$ I-Insulin binding and insulin stimulation of glycogen synthase were examined in fibroblasts cultured from nine Type 1 (insulin-dependent) diabetic patients with age of onset of $<42$ years. In all cases specific insulin binding was qualitatively and quantitatively normal. Total ${ }^{125}$ I-insulin binding was elevated in cells from three patients with early onset diabetes (two with onset before age 1 year) due to an increase in 'non-specific' binding. When the ability of insulin to stimulate the conversion of the glucose-6-phosphate dependent to the glucose-6-phosphate independent form of glycogen synthase was measured, all cell lines responded, albeit to differing degrees. In general, the response of cells from diabetic donors was more variable than that of control fibroblasts. A slightly lower level of cellular glycogen was evident in the cells of the diabetic patients, and this was mirrored in slightly high-
\end{abstract}

er levels of the independent form of the enzyme. The average maximal level of the independent form of the enzyme also was higher in the diabetic patients' cells. Fibroblasts from one of the patients with very early onset diabetes had glycogen synthase levels that were markedly lower than in any other cell line examined. In summary, fibroblasts cultured from Type 1 diabetic patients do not show major defects in either insulin binding or action. A suggestion of subtle differences in the cells from the diabetic patients, particularly those with very early onset, is evident, however. Whether these are secondary to some primary genetic defect or represent some selection during culture remains to be determined.

Key words: Human fibroblasts, insulin receptors, glycogen synthase, Type 1 diabetes.
Since the first link in the chain of events leading to insulin's bioeffects is binding to a cell surface receptor, it is advantageous to be able to study both binding and action in an accessible human tissue. By using fibroblasts cultured from patients with rare forms of insulin resistance, defects at the receptor [1, 2], post-receptor levels [3], or both [4], have been demonstrated. However, no studies of both binding and insulin action have been published on more classical forms of diabetes.

Even though early onset Type 1 (insulin-dependent) diabetes mellitus has its primary lesion in the B cells of the pancreas, it is reasonable to examine an insulin responsive tissue for other genetic changes in either insulin receptors or insulin action. Fibroblasts cultured from diabetic patients have been examined as regards a number of growth and metabolic parameters and a variety of abnormalities have been suggested. Recently, Raizada et al. studied insulin receptors and insulin-stimulated metabolic events in fibroblasts cultured from genetically diabetic mice [5]. They report that fibroblasts from $d b / d b$ mice have fewer insulin receptors and, also, poorer insulin stimulation of both 2-deoxy-glucose transport and ornithine decarboxylase activity.
As a measure of an event which is stimulated by insulin in human fibroblasts, we have chosen to look at the activation of glycogen synthase [6]. Insulin exerts its effect on this enzyme by stimulating a phosphatase which converts the phosphorylated dependent form of the enzyme to the partially dephosphorylated independent form. This has been carefully studied in rat adipocytes and also examined in a variety of other tissues and cultured cells [7-9]. In this report we present data on both insulin binding and insulin stimulation of glycogen synthase in cell lines from nine Type 1 diabetic patients compared with control subjects.

\section{Materials and Methods}

The following reagents were purchased from the sources indicated: fetal bovine serum and Eagle's minimal essential media (Biofluids, Rockville, Maryland); porcine insulin (Elanco Products, Indianapolis, Indiana); uridine diphospho- $\left[{ }^{14} \mathrm{Cl}\right.$-glucose (New England Nuclear, Boston, Massachusetts); trypsin for binding studies (Worthington Biochemicals, Freehold, New Jersey). All other reagents were of reagent grade and obtained from standard chemical supply houses. ${ }^{125} \mathrm{I}$-insulin was prepared by the chloramine-T method at specific aclivities of $80-150 \mu \mathrm{Ci} / \mu \mathrm{g}[10]$. 


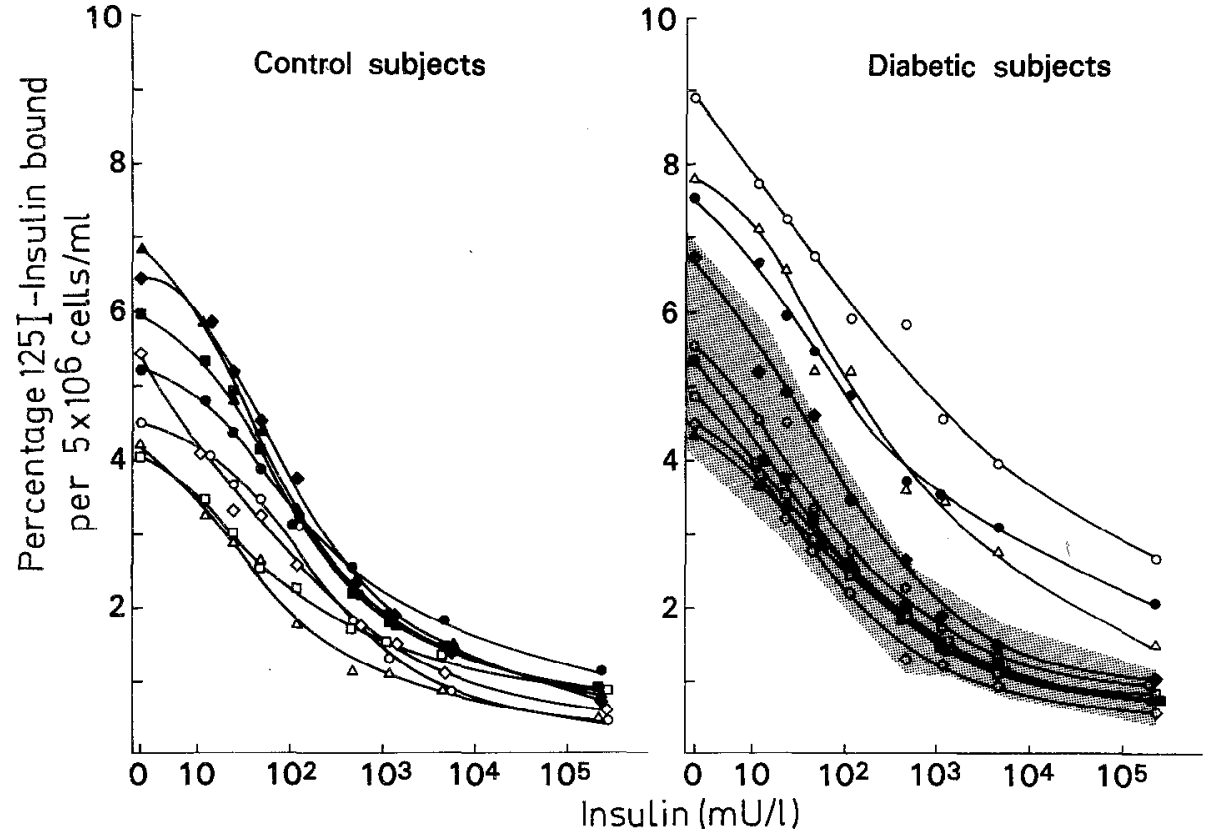

Fig. 1. Insulin binding to cultured human fibroblasts. Between 2 and $6 \times 10^{6}$ cells were used in each experiment and the results corrected to $5 \times 10^{6}$ cells $/ \mathrm{ml}$. Percentage ${ }^{125} \mathrm{I}$-insulin bound per $5 \times 10^{6}$ cells $/ \mathrm{ml}$ is plotted against the concentrations of unlabelled insulin added. Control subjects: The mean of four experiments (subject 8 , $\diamond$ ), three experiments (subjects 1,$0 ; 4, \Delta$; $6, \square$ ), or two experiments (subjects 2,$0 ; 3$, $\Delta ; 5, \mathbf{\square} ; 7, \bullet$ ) are shown for each control cell line used. Diabetic subjects: The mean of four experiments (patient $6, \square$ ), three experiments (patients $1, \bullet ; 2,0 ; 3, \wedge ; 4$, $\Delta ; 9, \bigcirc)$, or two experiments (patients 5 , - $7, \mathbf{7} ; 8, \diamond)$ are plotted. The shaded area represents the entire range of the eight control cell lines

\section{Cell Culture}

Fibroblast cultures were initiated from punch biopsies of the forearm [11]. Normal volunteers were age- and sex-matched, in good health at the time of biopsy, and had no family history of diabetes. Informed consent was obtained from both patients and controls. Cells were maintained in Eagle's minimal essential media supplemented with $20 \%$ fetal bovine serum and non-essential amino acids (complete media). The fibroblasts were subcultered at a $1: 3$ split ratio with $0.25 \%$ trypsin $/ 0.5 \mathrm{mmol} / \mathrm{l}$ EDTA in calcium and magnesium free phosphate buffered saline every 7-10 days. Cells were incubated at $37^{\circ} \mathrm{C}$ in a humidified $\mathrm{CO}_{2}$ incubator and used between passages 4 and 16 .

\section{${ }^{125}$ I-Insulin Binding}

Cells were plated in $100 \mathrm{~mm}$ dishes in complete media. The monolayers were confluent and used for experiments 4-7 days after subculture. Cells were detached by sequential treatment with $\mathrm{Ca}^{++}$and $\mathrm{Mg}^{++}$;free Dulbecco's phosphate buffered saline and mild trypsinization as described previously [12]. Cells were washed once in Hepes binding buffer $\left(118 \mathrm{mmol} / 1 \mathrm{NaCl}, 5 \mathrm{mmol} / 1 \mathrm{KCl}, 1.2 \mathrm{mmol} / 1 \mathrm{MgSO}_{4}\right.$, $8.8 \mathrm{mmol} / 1 \mathrm{D}$-glucose, $1 \%$ bovine serum albumin, $100 \mathrm{mmol} / 1$ Hepes at $\mathrm{pH} \mathrm{8.0)}$ and then resuspended to a concentration of $2-10 \times 10^{6}$ cells $/ \mathrm{ml}$. Cell suspension $(400 \mu \mathrm{l})$ was added to approximately $200 \mathrm{pg}$ of ${ }^{125} \mathrm{I}$-insulin and the appropriate concentration of unlabelled insulin in a volume of $100 \mu 1$ Hepes binding buffer at $15^{\circ} \mathrm{C}$. After incubation for $4 \mathrm{~h}$, duplicate $200 \mu \mathrm{l}$ aliquots from each tube were added to $0.4 \mathrm{ml}$ microcentrifuge tubes containing $200 \mu 1$ cold Hepes binding buffer and centrifuged in a Beckman Model B microfuge. The supernatant was aspirated and the radioactivity in the cell pellets counted in a Searle 1285 gamma counter at $80 \%$ efficiency.

\section{Glycogen Synthase Assay [6]}

Cells were plated in $100 \mathrm{~mm}$ dishes in complete medium and incubated for 8 days after which time the medium was changed to glucose and serum-free medium containing $0.1 \%$ bovine serum albumin for $24 \mathrm{~h}$. The medium was then replaced with $3 \mathrm{ml}$ of fresh glucose and serum-free medium with or without insulin for $1 \mathrm{~h}$ at $37^{\circ} \mathrm{C}$. The cells were then washed once with cold NaF-EDTA solution $(100 \mathrm{mmol} / 1$ $\mathrm{NaF}-10 \mathrm{mmol} / 1$ EDTA), scraped with a rubber policeman and collected by centrifugation ( $500 \mathrm{~g}$ for $2 \mathrm{~min}$ ). Cells collected from two dishes were resuspended in NaF-EDTA solution, transferred to $1.5 \mathrm{ml}$ microcentrifuge tubes, and sonicated for $10 \mathrm{~s}$ with a Biosonik sonicator at a setting of 20 . The tubes were then centrifuged in a Beckman Model B microfuge and the supernatant tested for glycogen synthase activity using the methods of Thomas et al. [13] and Huang and Cabib [14]. Cell supernatant ( $30 \mu 1)$ was added to $60 \mu \mathrm{l}$ of a solution containing $50 \mathrm{mmol} / 1$ Tris ( $\mathrm{pH} 7.8$ ), $20 \mathrm{mmol} / 1$ EDTA, $25 \mathrm{mmol} / 1$ $\mathrm{NaF}, 10 \mathrm{~g} / 1$ glycogen, $6.7 \mathrm{mmol} / \mathrm{l}$ uridine diphosphoglucose, and $100,000 \mathrm{cpm}$ of ${ }^{14} \mathrm{C}$-UDPG (sp. act. $229 \mathrm{mCi} / \mathrm{mmol}$ ). Half of the tubes contained $7.2 \mathrm{mmol} / \mathrm{l}$ glucose-6-phosphate. After mixing, the samples were incubated for $20 \mathrm{~min}$ at $30^{\circ} \mathrm{C}$ then $50 \mathrm{ul}$ from each tube was spotted on individual cellulose chromatography strips. These were subjected to ascending chromatography in $66 \%$ ethanol $/ 0.1 \mathrm{~mol} / \mathrm{l}$ ammonium acetate. The strips were air dried and the radioactivity in the portion corresponding to glycogen determined in a Searle liquid scintillation counter.

Independent glycogen synthase activity is defined as that measured in the absence of glucose-6-phosphate (G-6 P); total activity that measured in the presence of G-6-P. Percent independent activity is determined as the ratio of the independent-form to total activity. Glycogen was determined by the method of Lo et al. [15] after solubilization of the cells with $0.1 \%$ sodium lauryl sulphate, addition of $\mathrm{Na}_{2} \mathrm{SO}_{4}$, and precipitation with ethanol. Protein determinations were performed using the method of Lowry et al. [16].

\section{Results}

\section{${ }^{125}$ I-Insulin Binding}

${ }^{125} \mathrm{I}$-Insulin binding was assessed in cells from eight control subjects (four male, four female, age range: 0.7 to 44 years) and from nine Type 1 diabetic patients (four male, five female, age range: 0.5 to 60 years; age at onset of diabetes: < 1 to 42 years). Data obtained on each of the control cell lines, which were studied individually two to four times, are shown in Figure 1 a (total number of studies: 21). The reproducibility of the technique is such that repeated experiments on a single cell line over a period of 3 months result in standard deviations for total binding of $<1.5 \%$ [17]. This variation has never been a factor in determining a 'low' [17] or a 'high' binding cell line and is most probably due to small differ- 


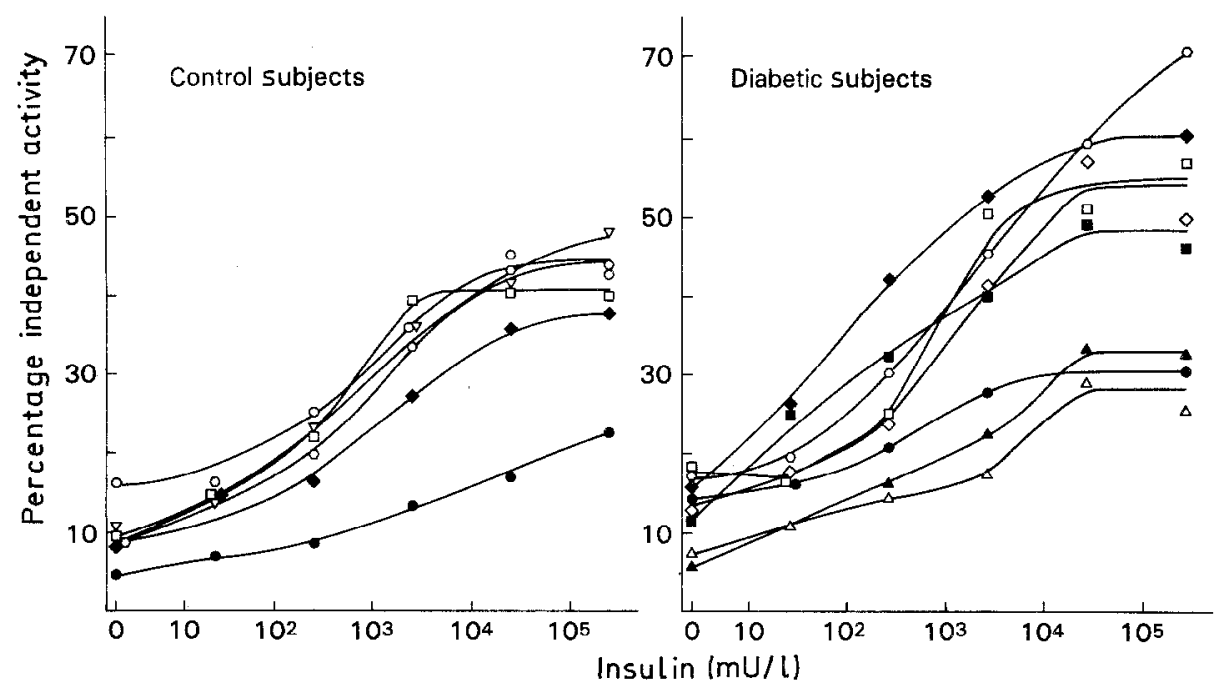

Fig. 2. Insulin stimulation of glycogen synthase in cultured human fibroblasts. Control subjects: The average of two experiments on each of four control cell lines is plotted as percentage independent activity versus insulin concentration. The average of duplicate experiments with cell lines from two insulin resistant patients, one of unknown origin, the other with the Type B syndrome characterized by insulin resistance attributable to circulating autoantibodies to the insulin receptor, are also in. cluded $(0, \nabla)$. Diabetic subjects: Data from experiments using eight cell lines from diabetic patients are presented in the same manner. The symbols are those given in the legend to Fig. 1

ences in individual iodinated insulin preparations. Total ${ }^{125} \mathrm{I}$-insulin binding averaged $5.35 \%$ per $5 \times 10^{6}$ cells $/ \mathrm{ml}$ (range: $4.0-6.9 \%$ ) and the concentration of insulin required to inhibit $50 \%$ of the tracer binding was $88 \pm 35 \mathrm{mU} / 1$ (mean $\pm \mathrm{SD}$ ).

When studied in the same way, six of the cell lines from Type 1 diabetic patients exhibited competition curves for ${ }^{125}$ I-insulin binding that were indistinguishable from the control subjects (Fig.1b). In fibroblasts from three patients (Nos 1, 2 and 4 - No. 1 male; Nos 2 and 4 female; ages: $0.5,27$ and 15 years; duration of diabetes: $<0.5,<1$ and 12 years respectively), total ${ }^{125} \mathrm{I}$ insulin binding was elevated. This was not due to a change in specific insulin binding. Rather, there was an elevation in the level of non-specific binding (i.e., the amount of ${ }^{125} \mathrm{I}$-insulin binding remaining in the presence of $250 \mathrm{U} / 1$ unlabelled insulin). The integrity of the ${ }^{125}$ I-insulin before and after incubation with any of these cell lines was unchanged as determined by either trichloroacetic acid or insulin-antibody precipitation (data not shown). The concentration of insulin which inhibited insulin binding by $50 \%\left(1 / 2 \mathrm{~B}_{\max }\right)$ for the fibroblasts from Type 1 diabetic patients was normal (range $80-250 \mathrm{mU} / 1$ ). The $1 / 2 \mathrm{~B}_{\max }$ for the three cell lines with the highest levels of non-specific binding were the highest among the nine patients $(225,200$, and $125 \mathrm{mU} /$ 1); however, these were still within the range of normal.

\section{Glycogen Synthase}

In normal human fibroblasts about $10 \%$ of the glycogen synthase activity in quiescent cultures was in the dephosphorylated or independent form. Upon incubation with insulin, the percentage of the enzyme in the independent form increased by three to fivefold (Figs. 2 and 3). Cells from the youngest control subject (age 8 months) had the lowest basal and lowest stimulated values. Half-maximal stimulation of the conversion of the dependent to the independent form of the enzyme was achieved with $950 \pm 525 \mathrm{mU} / 1$ (mean $\pm \mathrm{SD}$ ) insulin in control cells (Fig. 2).

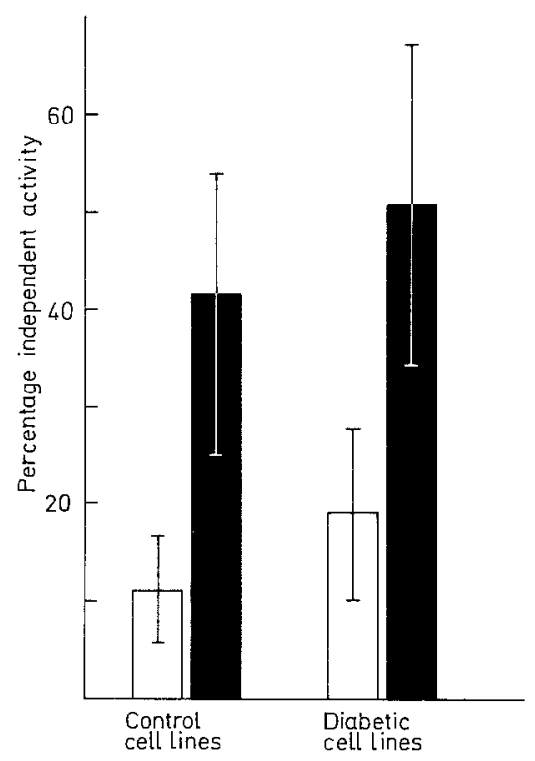

Fig. 3. Basal and stimulated levels of percentage independent activity. Cells were plated and then assayed for glycogen synthase as in Methods. Incubations were either without ( $\square$ ) or with (E) $250 \mathrm{U} / \mathrm{l}$ insulin. The results are expressed as mean \pm SD for 20 experiments with control cells and 24 with diabetic cells

Cells from the Type 1 diabetic patients exhibited insulin stimulation of glycogen synthase. In general, the percentage of glycogen synthase in its independent form in the basal state in the fibroblasts from diabetic donors was greater than that of control cells although this did not reach statistical significance (19\% versus 11\%); (Fig. 3). Likewise, maximally stimulated levels of percentage independent activity ( $250 \mathrm{U} / 1$ insulin) were proportionately higher than the controls (Fig. 3). In both groups the absolute increase in percentage independent activity was about 30\% (stimulated level - basal level). Dose response curves were performed on eight of the nine cell lines. These revealed a range that was much greater than in the control studies performed during the same time period (Fig. 2), although the mean level for half-maximal response was similar to that in control 


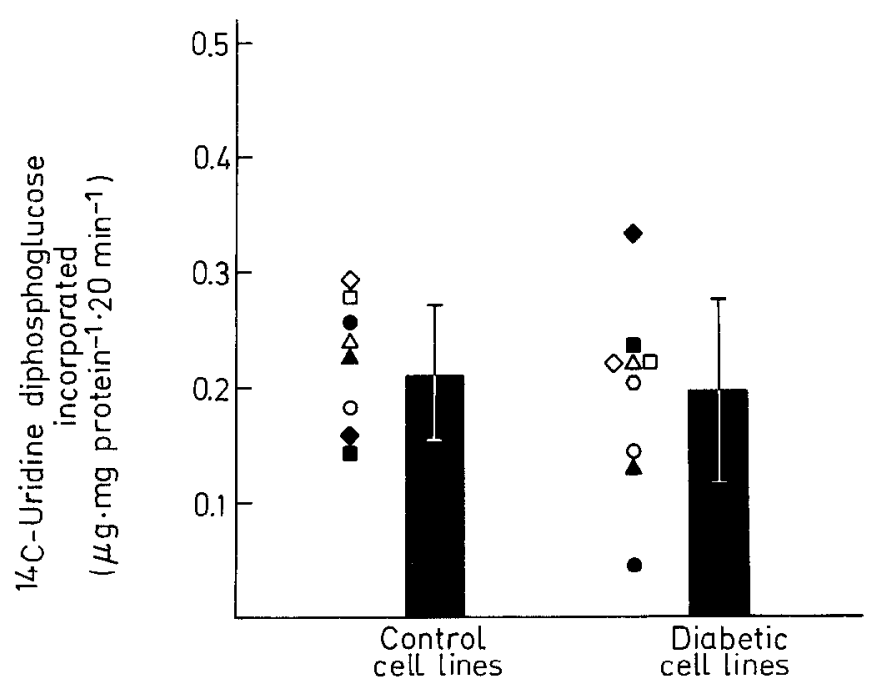

Fig.4. Total glycogen synthase activity. Aliquots of the sonicates used for enzyme assay were used for protein determination in multiple samples from several experiments for each cell line. Results are expressed as mean $\pm \mathrm{SD}$ : control cell lines $0.212 \pm 0.059$ and diabetic cell lines $0.197 \pm 0.08 \mu \mathrm{mol}{ }^{14} \mathrm{C}$-uridine diphosphoglucose incorporated $\left(\mu \mathrm{mol} \cdot \mathrm{mg}\right.$ protein $\left.{ }^{-1} \cdot 20 \mathrm{~min}^{-1}\right)$

subjects $(900 \pm 750 \mathrm{mU} / 1)$. Interestingly, patients 1 and 2 had the poorest insulin response curves in the glycogen synthase assay, but the highest levels of total insulin binding (Fig. 1).

One factor that may account for the higher basal percentage independent activity in the diabetic-derived cells is their correspondingly lower cellular glycogen stores. The value for control cell lines was $118 \pm 61 \mu \mathrm{g}$ glycogen $/ \mathrm{mg}$ protein (mean $\pm \mathrm{SD}$ ) and for the diabetic lines was $81 \pm 38.5 \mu \mathrm{g} / \mathrm{mg}$. Again this does not reach statistical significance due to the large standard deviations. We have observed an inverse correlation between glycogen levels and percentage independent activity in human fibroblasts in some insulin resistant patients [18]. The total amounts of glycogen synthase in all but one diabetic cell lines were the same as those in control fibroblasts (Fig.4). In the single patient who differed (No. 1 ; male; age 0.5 years, onset $<0.5$ years), levels of glycogen synthase were consistently lower than those found in any cell line tested to date.

\section{Discussion}

Over the last 20 years there have been many studies on fibroblasts cultured from diabetic patients. Most of these reports have dealt mainly with Type 1 diabetes and demonstrated that the cells from diabetic donors were abnormal in a variety of ways. These include decreased plating efficiency and growth for cells of prediabetic subjects, Types 1 and 2 diabetic patients [19-23], faulty stimulation of protein synthesis by hydrocortisone (Type 1 diabetes) [24], increased acetate utilization [25], excessive cross-linking of collagen (Type 1 diabetes) [26], abnormal glycosaminoglycan secretion
(Types 1 and 2 diabetes) [27], and defects in glycogen synthase (Type 1 diabetes) [28]. Not in every case have these abnormalities been confirmed. For example, Rosenbloom has found that Type 1 diabetic fibroblasts exhibit normal not decreased growth [29] and this is also true for Type 2 Pima Indian patients studied by Howard et al. [30]. Also, other authors have presented data to show that in diabetic fibroblasts the low density lipoprotein receptor is normal [31], as is the ability of insulin to stimulate the production of carbon dioxide from glucose [32]. Thus far there have been no systematic studies of insulin binding to fibroblasts from diabetic patients. In view of the slowly accumulating evidence that fibroblasts from diabetic donors exhibit genetic abnormalities, it seemed appropriate to do so.

In the cell lines derived from nine Type 1 diabetic patients studied here, most exhibited normal insulin binding and biological response. However, some subtle abnormalities were noted. Three cell lines had levels of non-specific binding that were consistently higher than in all other patients and normal subjects. These were fibroblasts from three of four patients whose insulin dependency began before the age of 12 years. In two of these the diabetes was diagnosed during the first year of life. In these cell lines insulin stimulation of glycogen synthase was examined over the entire range of insulin concentrations and the cells seemed to be less responsive than most of the controls or other diabetic lines.

The tendency of the cells of patients with early onset diabetes to segregate from the rest of the patients' cells also is apparent in the levels of enzyme in these fibroblasts. Three of the patients presenting at the earliest ages had the three lowest levels of glycogen synthase among the diabetic cell lines. Because we studied only a limited number of patients, this tendency will need to be evaluated in many more cell lines.

Whether this trend is the fault of the insulin receptor or just reflects the variability among cell lines is difficult to evaluate. Since cells from both Type 1 and 2 diabetic patients may be less able to withstand cultivation in vitro $[19,20]$, this lack of responsiveness could be merely a result of selection of a subpopulation of diabetic fibroblasts different from that observed in normal subjects or a reflection of the cells overall poor adaptation to culture. Supportive of this is the fact that the cells from the diabetic patients had, on the average, less glycogen than the control cell lines.

Our results on glycogen synthase are somewhat at variance with those of Craig et al. who found that fibroblasts from three Type 1 diabetic subjects had lower than normal percentage independent activity in the unstimulated state and poorer insulin stimulation than normal subjects although the difference did not reach statistical significance [28]. One explanation for this difference could be the response of the diabetic patients' cells to glucose deprivation, since in our studies, the cells were starved for $24 \mathrm{~h}$ before the glycogen synthase assay to maximize the insulin response. This does not change the growth parameters of the cells (data not shown) and should not adversely affect energy metabo- 
lism since the cells are studied at confluency and glutamine is supplied in excess [33].

In summary, these data suggest that most cell lines from Type 1 diabetic subjects have specific ${ }^{125} \mathrm{I}$-insulin binding which is normal. In a few diabetic lines, however, non-specific insulin binding is increased. Cells from diabetic donors tend to exhibit minor abnormalities in basal or insulin-stimulated glycogen synthase, but the results are not dramatic. This has unfortunately been the case in many of the differences reported in fibroblasts from diabetic patients $[19-23,25,28]$. These findings suggest to us that cells from diabetic subjects removed from their abnormal metabolic milieu continue to show subtle cellular metabolic defects. Whether this reflects selection of cell populations before or during the culture of the fibroblasts or is a manifestation of some other, perhaps primary, defect in these cells is uncertain. That differences, however subtle, continue to be found in cultured cells should lead to more intensive investigation of possible genetic factors other than insulin deficiency which may alter these cellular events.

Acknowledgements. This work was done in partial fulfillment of the Ph. D. thesis requirements for JMP at George Washington University. We thank Dr. R.Schwartz for kindly providing fibroblast cultures from patients 1 and 2 .

\section{References}

1. Dörfler H, Wieczorek A, Wolfram G, Zöllner N (1977) Binding of insulin to fibroblasts in lipoatrophic diabetes. Res Exp Med 170: 161-168

2. D'Ercole AJ, Underwood L, Groelke J, Plet A (1979) Leprechaunism: Studies of the relationship among hyperinsulinism, insulin resistance, and growth retardation. J Clin Endocrinol Metab 48: 495-502

3. Kobayashi M, Olefsky JM, Elders J, Mako ME, Givens BD, Schwedie HK, Fisler RH, Hintz RL, Horner JA, Rubenstein AH (1978) Insulin resistance due to a defect distal to the insulin receptor: Demonstration in a patient with leprechaunism. Proc Natl Acad Sci USA 75: 3469-3473

4. Schilling E, Rechler M, Grunfeld C, Rosenberg A (1979) Primary defect of insulin receptors in skin fibroblasts cultured from an infant with leprechaunism and insulin resistance. Proc Natl Acad Sci USA 76: $5877-5881$

5. Raizada M, Tan G, Fellows R (1980) Fibroblast cultures from the diabetic $\mathrm{db} / \mathrm{db}$ mouse. J Biol Chem 255: 9149-9155

6. Podskalny JM, Kahn CR (1980) Insulin activates glycogen synthase in cultured human fibroblasts. Diabetes 29: 724-729

7. Lawrence JC, Guinovart J, Larner J (1977) Activation of rat adipocyte glycogen synthase by insulin. J Biol Chem 252: 444-450

8. Alpers J (1966) The influence of hexose and insulin on glycogen synthase in hela cells. J Biol Chem 241: 217-222

9. Huang K (1979) Regulation of glycogen synthase activity in choriocarcinoma cells. Eur J Biochem 95: 477-485

10. Freychet P, Kahn CR, Roth J, Neville Jr, DM (1972) Insulin interaction with liver plasma membranes. J Biol Chem 247: 3953-3961

11. Rechler M, Podskalny J, Goldfine I, Wells C (1974) DNA synthesis in human fibroblasts: stimulation by insulin and by non-suppressible insulin-like activity. J Clin Endocrinol Metab 39: 512-521

12. Rechler MM, Podskalny JM (1976) Insulin receptors in cultured human fibroblasts. Diabetes $25: 250-255$

13. Thomas J, Schlender K, Larner J (1968) A rapid filter paper assay for UDP glucose-glycogen glucosyltransferase, including an improved biosynthesis of UDP. ${ }^{14} \mathrm{C}$-glucose. Anal Biochem 25: $486-499$
14. Huang K, Cabib E (1973) Yeast glycogen synthase in the glucose6-phosphate-independent form: a case of cold liability without major changes in molecular size. Biochem Biophys Acta 302: $240-248$

15. Lo S, Russell JC, Taylor AW (1970) Determination of glycogen in small tissue samples. J App Physiol 28: 234-236

16. Lowry OH, Rosebrough NJ, Farr AL, Randall RJ (1951) Protein measurement with the folin phenol reagent. J Biol Chem 193: $265-269$

17. Podskalny J, Kahn CR (1982) Cell culture studies on patients with extreme insulin resistance. I. Receptor defects on cultured fibroblasts. J Clin Endocrinol Metab 54: 261-268

18. Podskalny J, Kahn CR (1982) Cell culture studies on patients with extreme insulin resistance. II. Abnormal biological responses in cultured fibroblasts. J Clin Endocrinol Metab 54:269-275

19. Goldstein S, Littlefield JW, Soeldner JS (1979) Diabetes mellitus and aging: diminished plating efficiency of cultured human fibroblasts. Proc Natl Acad Sci USA 64: 155-160

20. Goldstein S, Moerman EJ, Soeldner JS, Gleason RE, Barnett DM (1979) Diabetes mellitus and genetic prediabetics: decreased replicative capactiy of cultured skin fibroblasts. J Clin Invest 63: 358-370

21. Vracko R, Benditt EP (1975) Restricted replicative life-span of diabetic fibroblasts in vitro: its relation to micorangiopathy. Fed Proc 34: $68-70$

22. Goldstein S, Moerman E, Soeldner JS, Gleason RE, Barnett DM (1978) Chronologic and physiologic age affect replicative lifespan of fibroblasts from diabetic, pre-diabetic, and normal donors. Science 199: 781-782

23. Gleason RE, Goldstein S (1978) Age affect and replicative lifespan of fibroblasts of diabetic, prediabetic, and normal donors: another look at the data. Science 212: 1217-1218

24. Rowe DW, Starman BJ, Fujimoto WY, Williams RH (1977) Abnormalities in proliferation and protein synthesis in skin fibroblast cultures from patients with diabetes mellitus. Diabetes 26: 284-290

25. Cooper JT, Goldstein S (1974) De novo synthesis of lipids and incorporation of oleic acid into cultured human fibroblasts from diabetics and normal controls. Atherosclerosis 20:41-50

26. Kohn RR, Hensse S (1977) Abnormal collagen in cultures of fibroblasts from human beings with diabetes mellitus. Biochem Biophys Res Commun 76: 765-771

27. Silbert CK, Kleinman HK (1978) Studies of cultured human fibroblasts in diabetes mellitus: changes in heparan sulfate. Diabetes 28: 61-65

28. Craig JW, Huang LS, Larner J (1980) Insulin stimulation of glycogen synthase activity in cultured human fibroblasts from diabetic and control subjects. Diabetologia 18: 109-113

29. Rosenbloom AL, Rosenbloom EK (1978) Insulin-dependent childhood diabetes: normal viability of cultured fibroblasts. Diabetes $27: 338-341$

30. Howard B, Fields R, Mott D, Savage P, Nagulesparan M, Bennett $P$ (1980) Diabetes and cell growth: lack of differences in growth characteristics of fibroblasts from diabetic and non-diabetic Pima indians. Diabetes 29: 119-124

31. Chait A, Bierman E, Albers J (1979) Low density lipoprotein receptor activity in fibroblasts cultured from diabetic donors. Diabetes 28: 914-918

32. Goldstein S, Littlefield JW (1969) Effect of insulin on the conversion of glucose-C-14 to $\mathrm{C}-14-\mathrm{O}_{2}$ by nornal and diabetic fibroblasts in culture. Diabetes 18: 545-549

33. Zielke HR, Ozand PT, Tildon JT, Sevdalian DA, Cornblath M (1976) Growth of human diploid fibroblasts in the absence of glucose utilization. Proc Natl Acad Sci USA 73: 4110-4114

Received: 2 July 1981

and in revised form: 21 June 1982

Dr. J.M. Podskalny

Building 10, Room 8-South-243

National Institutes of Health

Bethesda, MD 20205

USA 